
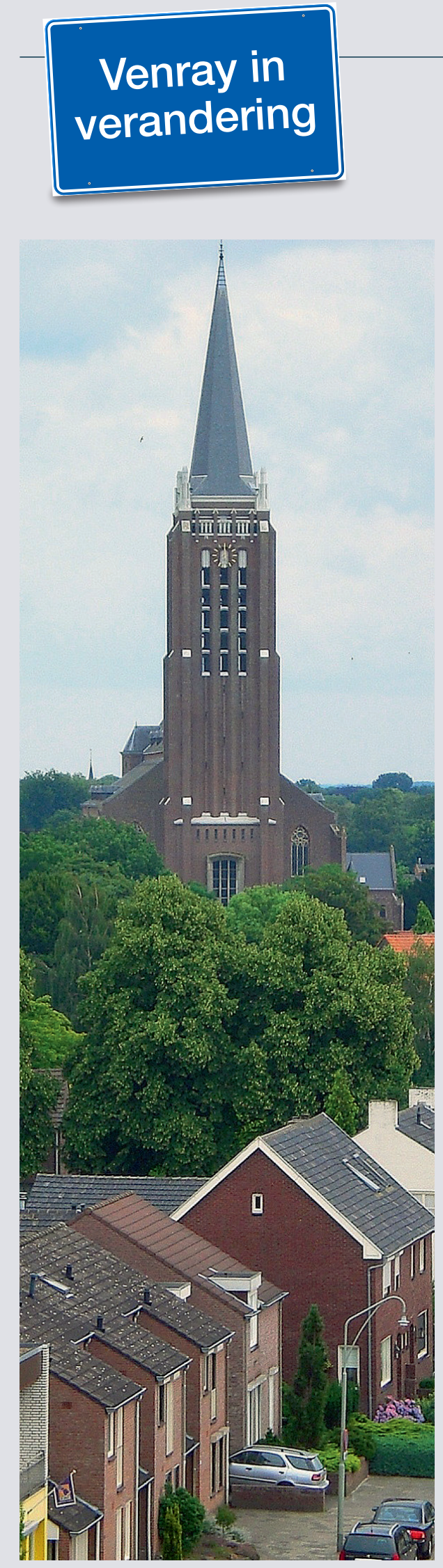

\title{
De Burgertop die niet zo zal heten
}

\section{Dezelfde enthousiaste Venraynaren die begin 2017 een succesvolle Burgertop organiseerden, bereiden} nu een vervolg voor. Venray-watcher Stan Verhaag is erbij - en gaat opnieuw voor de bijl.

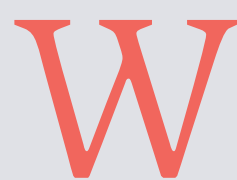

at voorafging. Begin 2017 organiseerde een clubje van tien enthousiaste Venraynaren de eerste Burgertop. In de plaatselijke Evenementenhal bedachten ruim honderd inwoners een hele zaterdag nieuwe initiatieven. Mensen zoals u en ik waren erbij, maar ook wethouders (in trui) en ambtenaren. De sfeer was uitgelaten; het ongebreidelde enthousiasme van dagvoorzitter Tom Vaessen en zijn team sloeg over. Aan het eind beloofden we plechtig van Venray een nog fijnere gemeente te maken.

$\mathrm{Nu}$, in september 2018, zitten we met een man of twintig op een vrijdagmiddag bij elkaar in het gebouw van ROC Gilde. Het idee is dat we de tweede Burgertop gaan voorbereiden. Maar eerst steekt een van de deelnemers zijn vinger op: 'Hoeveel initiatieven zijn er van de grond gekomen na de eerste Burgertop?', vraagt hij. 'Eentje heeft het een tijdje volgehouden, eentje bestaat nog steeds,' antwoordt een van de organisatoren. Dan volgt er zo'n moment dat bekendstaat als pijnlijke stilte: die paar seconden waarin niemand zegt wat iedereen denkt. Namelijk dat dat eigenlijk best wel een schamele oogst is gezien het euforische gevoel waarmee iedereen destijds naar huis ging.

Maar de organisatoren hebben hun lesje geleerd: 'Omdat we gemerkt hebben dat er al veel initiatieven zijn, willen wij een nieuwe invulling geven aan onze burgerbeweging', lees ik in de uitnodiging. 'Onze vernieuwde doelstelling is inwoners met mooie ideeën, bestaande initiatieven en verenigingen en stichtingen die met allerlei plannen en evenementen bezig zijn op 2 februari 2019 een platform aan te bieden dat hun initiatieven versterkt (verbinding, inzicht, kennis, tools) en hen in contact brengt met andere of vergelijkbare ideeën (inspiratie, verbreding).'

Op deze vrijdag is er eerst vlaai, gemaakt door leerlingen van ROC Gilde. Om zes uur eten we een gezamenlijke maaltijd waarvan de onderdelen zijn bereid door de tien organisatoren ('Aan deze salade met pesto zijn mijn vriendin en ik jaren verslaafd geweest'). En tussendoor gaan we naar buiten, waar Vaessen ons verleidt om mee te doen aan een 'energizer': kies in gedachten twee andere deelnemers en stel jezelf tussen hen op. 'Oké, daar gaan we! Allemaal tegelijk!' Probeer dan maar eens sceptisch te blijven. Zo voltrekt zich het wonderbaarlijke: vier uur lang(!) doet iedereen enthousiast mee. In vijf groepjes bedenken we hoe we op 2 februari de deelnemers een platform kunnen bieden. Er worden kritische vragen gesteld ('Hoe bereiken we de jeugd en de gekleurde Venraynaar, die vandaag beiden schitteren door afwezigheid?'), maar aan het eind liggen er weer volop ideeën om van Burgertop 2 een succes te maken - inclusief ideeën voor een andere naam. Zijn we er toch ingetuind?, vraag ik mij af als ik naar huis rijd. Of pakken ze het gewoon slim aan, met hun nieuwe invulling, andere naam en zelfde enthousiasme? 